\title{
GLACIAL GEOMORPHOLOGICAL MAP (1:200 000) OF MT. TOMUR REGION, TIANSHAN \\ (Abstract)
}

\author{
by
}

\section{Zheng Benxing}

(Lanzhou Institute of Glaciology and Geocryology, Academia Sinica, Peking, China)

\begin{abstract}
The Glacial Geomorphological Map (1:200 000) of Mt. Tomur Region, Tianshan, covers $78^{\circ} 33^{\prime}-81^{\circ} 10^{\prime} \mathrm{E}$ and $41^{\circ} 08^{\prime}-42^{\circ} 44^{\prime} \mathrm{N}$, with high mountains, deep valleys and many snow peaks, the highest being Mt. Tomur (7435.3 a.s.1.). There are many glaciers in this region with a total area of $4553.69 \mathrm{~km}^{2}$. The melt water from glaciers irrigates the large oasis of Aksu, in the piedmont region in southern Xingjiang and waters the valley plain of Teks River in the Yili area. From piedmont plain to highest mountain summit, the vertical zonality of geomorphology is quite clear, rich in various geomorphological types, representing alpine geomorphology of the arid desert in Central Asia.

The author joined the glacial/geomorphological expedition to the Mt. Tomur Region in 1963, 1973 and 1974, and, in the process of mapping, cooperated closely with mapping engineers. This involved extensive use of aerial photographs, satellite images, large-scale topographic maps, geological maps, geomorphological maps and other data, and comprehensive analyses, comparisons and judgements of data
\end{abstract}

Special emphasis was placed on existing glaciers and the geomorphology of Quaternary glaciers, according to form, composition and relative chronological periods. The geomorphology was divided into five great systems, i.e. glacial, fluvio-glacial, fluvial, arid and artificial. Twenty-four geomorphic types were defined as the basic elements of the geomorphological map and shown in different colours and by various marks, while old and Neozoic faults were shown by black line marks. There are representative heights on all geomorphological zones. Colour brush-shading added much to the stereo effect.

Below the main map, the longitudinal and cross sections of Quaternary geology and geomorphology of the Tialan valley, the stratigraphical columnar profile of West Zamtia and the fluvial/lacustrine deposit profile of the Loska basin were attached, showing the stratigraphical relation between the glacial and non-glacial deposit and the basis for the divisions of the glacial and inter-glacial periods.

\section{MAPPING THE EXTENT AND DURATION OF SURFACE MELTING ON ICE SHEETS AND SHELVES}

\author{
(Abstract) \\ by \\ H. Jay Zwally
}

(NASA, Goddard Space Flight Center, Greenbelt, MD, U.S.A.)

\begin{abstract}
Previous studies have shown that the microwave brightness temperature $\left(\mathrm{T}_{\mathrm{B}}\right)$ of snow and firn increases markedly as the surface becomes wet (e.g. Stiles and Ulaby, 1980; and Zwally and Gloersen, 1977). For example, the $\mathrm{T}_{\mathrm{B}}$ at station Dye II $(66.5 \mathrm{~N}, 46.2 \mathrm{~W})$, on the Greenland ice sheet, as observed by the Nimbus- 5 microwave radiometer, increases abruptly from $170 \mathrm{~K}$ to $245 \mathrm{~K}$ during the summer melt period (Zwally, 1984). Now the Nimbus-5 microwave
\end{abstract}

data are analysed, using $\mathrm{T}_{\mathrm{B}}$ change criteria to map the extent and duration of summer melting of the surface of the Greenland Ice Sheet and several Antarctic ice shelves during 1973-1976. Inter-annual variations in the melt pattern are notable and several events are described in which the increased $\mathrm{T}_{\mathrm{B}}$ during the month of January outlines the ice streams flowing from West Antarctica into the Ross Ice Shelf. 